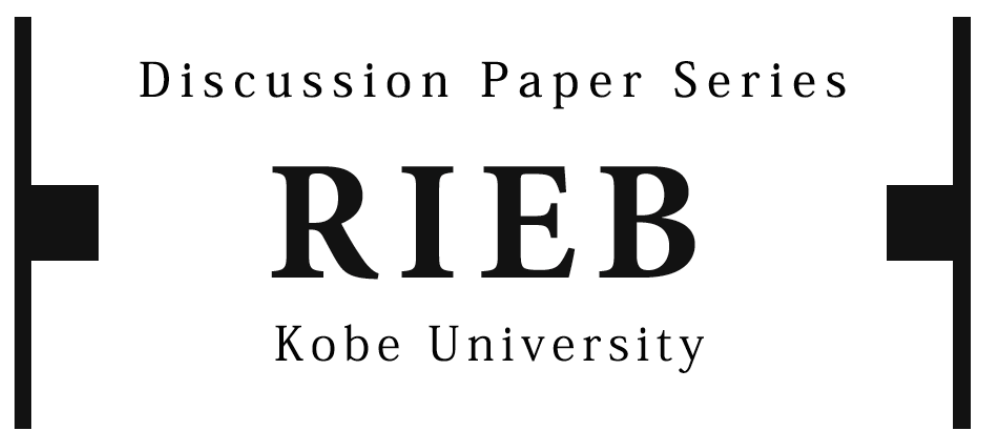

DP2020-03

\title{
Formal Institutional Uncertainty and Equity Sought on Foreign \\ Market Entry: \\ Does Industry Matter?
}

\author{
Kashif AHMED \\ Ralf BEBENROTH \\ Jean-François HENNART
}

January 16, 2020

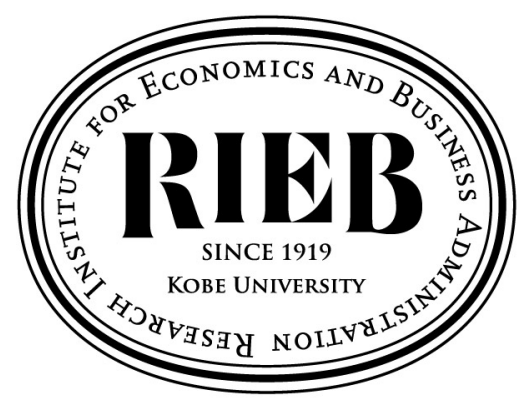

Research Institute for Economics and Business Administration

Kobe University

2-1 Rokkodai, Nada, Kobe 657-8501 JAPAN 
Formal institutional uncertainty and equity sought on foreign market entry:

Does industry matter?

\author{
Kashif Ahmed \\ (corresponding author) \\ $\mathrm{PhD}$ Student \\ Graduate School of Business Administration \\ Kobe University \\ 2-1 Rokkodai, Nada, Kobe 657-8501, Japan \\ kashif.ahmed@stu.kobe-u.ac.jp \\ Ralf Bebenroth \\ Professor \\ Research Institute for Economics \& \\ Business Administration (RIEB) \\ Kobe University \\ Shinkan 304, 2-1 Rokodai, Nada, Kobe 657-8501, Japan \\ rbeben@rieb.kobe-u.ac.jp \\ Jean-François Hennart \\ Tilburg University, Tilburg, The Netherlands; \\ Vienna University of Economics and Business, Vienna, Austria; \\ Politecnico di Milano, Milan, Italy \\ e-mail: j.f.hennart@uvt.nl
}


Formal institutional uncertainty and equity sought on foreign market entry: Does industry matter?

\begin{abstract}
This study examines how the effect of host country formal institutional uncertainty on the percentage of equity sought in cross border acquisitions is moderated by the host country industry (i.e. targets from the technology versus those from the non-technology industry). This study is based upon the legitimacy perspective of institutional theory and employs Tobit regression analysis on a sample of 1340 cross-border acquisitions.

Results show that cross-border acquirers prefer a lower equity level for targets in institutionally less developed countries, and that this negative effect of host country institutional risk on the equity percentage sought is more pronounced for technology-based targets. This study shows that the industry selected has a bearing on equity sought in cross-border acquisitions. Investing in institutionally less developed countries is particularly challenging when the targets of acquisition are in the technology industry.
\end{abstract}

Keywords: Institutional theory; cross-border acquisitions; percentage of equity sought; technology industry, host country formal institutional uncertainty 


\section{Introduction}

Firm ownership decisions in cross-border acquisitions are some of the most frequently studied topics in international business (IB) studies. Scholars contend that institutional distance between home and host countries, as well as the level of formal institutional uncertainty in host countries have to be taken into account when conducting cross-border acquisitions (CBAs). Accordingly, evidence shows that acquirers tend to opt for lower equity share in their cross-border targets when host country risk is higher (Chari and Chang, 2009). While the direct effect of institutional risk or uncertainty on the entry mode choice has been extensively investigated (Brouthers and Hennart, 2007), there are relatively fewer studies on moderating factors affecting this relationship (Ando, 2012; Arslan and Dikova, 2015; Cui and Jiang, 2012; Liou et al., 2017). The studies available show that diverse factors come into play, such as acquirer's international experience (Ando, 2012), acquirer's host country experience (Arslan and Dikova, 2015), state ownership of acquirer (Cui and Jiang, 2012), and even the stage of development of home country human resources (Liou et al., 2017). Nonetheless, a neglected area of research is how the type of industry affects the acquirer's response to formal institutional uncertainty in cross-border deals. In order to fill this gap in the literature, we theorize and empirically validate the relationship between host country formal institutional uncertainty and percentage of equity sought, and how this is moderated by the host country specific industry, focusing on targets in the technology industry versus those in the non-technology industry.

The technology industry is chosen in this study for two reasons. First, technology transfer is a major reason why firms internationalize (Graebner et al., 2010), thus highlighting the practical importance of this study. Second, the technology industry is also theoretically important for our study as we focus on firms ' responses to institutional uncertainty. Cui and Jiang (2012) reasoned that if a foreign acquirer was perceived negatively in the host country for possible opportunistic behavior, it would experience greater difficulty in gaining legitimacy (Kostova et al., 2008). It would thus experience greater institutional scrutiny by local politicians during the acquisition process. These firms would be under greater threat to conform to institutional pressure, and therefore, the negative effect of institutional uncertainty on the percentage of equity sought should be more pronounced. In the context of our study, host country governments consider it essential to protect their technology firms from diffusing abroad through cross-border acquisitions (Globerman and Shapiro, 2009). For this reason, crossborder acquirers seeking to acquire technological targets are perceived as a threat owing to their tendency for opportunistic behavior. Therefore, we expect that the effect of host country formal institutional uncertainty on the percentage of equity sought should be more pronounced for acquirers seeking targets in the technological sector.

To the best of the authors' knowledge, Elango et al. (2013) is the only study showing an interaction effect between institutional distance and technology targets in CBAs' market entry decision. However, their theoretical focus was on the moderating influence of institutional distance on the relationship between host country industry (technology versus non-technology) and percentage of equity sought. In contrast, our study focused on the moderating effect of the industry (technology versus others) on the relationship between institutional uncertainty and percentage of equity sought. Although the statistical test for either case relied on the interaction effect of the two variables, the underlying theoretical inquiry for both cases was entirely different. Moreover, the contextual focus of Elango et al. (2013) was limited to acquisitions in four major emerging economies, with their deals classified as 
technology-driven only when non-technology bidders took over technology targets. In contrast, we were more interested in the sector/industry the target was from, regardless of whether or not the bidder was from the technology industry. Also, we focused on worldwide acquisitions, albeit taken over by only Japanese firms. There were two major reasons for selecting Japanese companies for this study. First, Japan has actively borrowed from a multitude of foreign technologies to facilitate its local technological innovations (Petrescu, 2009). For this reason, we expected Japanese firms to conduct cross-border acquisitions also partly to enhance their technological prowess further. Second, the geographical location of Japan in East Asia makes it easy for Japanese firms to conduct acquisitions in numerous neighboring countries even if they are not much developed institutionally such as Malaysia or Thailand. Hence, although our sample was limited to acquiring firms only from Japan, our data still had substantial heterogeneity in the institutional development on the target side. Building on the study of Elango et al. (2013), we focused on a different set of research questions in the context of Japanese cross-border acquisitions.

Our results corroborated previous findings that the direct effect of institutional uncertainty on the percentage of equity sought was negative (Yiu and Makino, 2002; Cui and Jang, 2012). Moreover, confirming our expectations based upon the legitimacy perspective of institutional theory, the results showed that the effect of institutional uncertainty on the percentage of equity sought was more pronounced for targets in the technology sector. Our study contributes to the International Business (IB) literature in two ways. First, in confirming earlier findings in the IB literature about the effect of institutional uncertainty on percentage of equity sought, this study shows that Japanese firms indeed prefer lower equity in institutionally less developed countries. Second, by building upon the legitimacy perspective of institutional theory, our study shows that firms respond to institutional uncertainty in various ways, depending on the type of target sought by the CBA bidder. More specifically, we show that the effect of institutional uncertainty on the percentage of equity sought is more pronounced when acquirers seek technology targets.

Following the Introduction, the rest of the study is organized as follows. In the next section, we review relevant literature, followed by the development of two hypotheses. Next, we elaborate on the methods used in this study. We then present the results and robustness analysis, followed by a discussion. The study ends with limitations and suggestions for future research avenues.

\section{Theoretical background and hypothesis development}

\subsection{Formal institutional uncertainty}

Institutional theory deals with how social actors become isomorphic or similar to one another under the influence of institutional pressure (Dikova et al., 2010). Based on this theory, scholars argue that firms' decisions are influenced by a diverse set of social arrangements such as rules, norms and cultural aspects prevalent in a society. Proponents of this theory emphasize the central role of institutions as they provide the rules of the game which govern firms' economic behavior and interactions (Lahiri et al., 2014; North 1990; Peng et al., 2008; Scott, 2005). This idea has implications for how multinational firms are viewed. For example, scholars are aware that multinational firms are influenced by their host-country institutional environments where they set up production facilities. Thus, institutional theory has a high relevance for the context of mergers and acquisitions. For example, if the host country institutional environment is comparatively less developed, foreign 
bidders will face increased uncertainties in host country locations (Oguji and Owusu, 2017; Peng, 2002, 2003).

Institutional theory suggests that CBAs are affected by broadly two types of institutions, viz. formal and informal institutions (Dikova et al., 2010; Peng et al., 2008). Formal institutions comprise organizations such as regulatory bodies, law enforcement agencies, economic reform committees, etc. (Yiu and Makino, 2002). In contrast, informal institutions are embedded in social norms of the society (Lahiri et al., 2014). It is widely acknowledged that less developed economies have generally less developed formal institutions. In the context of cross-border acquisitions, this means that CBA bidder might face higher uncertainty in host countries with restrictive policies with respect to the acquisition, limited access to local resources, mandatory exporting requirement, or unnecessary interference in operational matters (Meyer et al., 2009). Such circumstances influence the level of shares which the foreign firm seeks to acquire when taking over a target. The foreign acquirer might opt for a lower shareholding of the target in the host country for smoother operations in the post-acquisition phase, allowing the local firm to participate more actively in, and even lead the business. Also, higher formal institutional uncertainty puts foreign firms at a disadvantage when competing against local firms (Cui and Jiang, 2012). As such, higher formal institutional uncertainty in the host country leads the bidder to seek lower equity in a cross-border acquisition. In summary, opting for a lower equity share in institutionally less developed countries minimizes cost and risk. Besides, partial acquisition gives the acquiring firm more flexibility as it has the option of increasing shareholding later. In this way, the level of uncertainty at the beginning of a given investment can be reduced. It would seem, therefore, logical for firms to seek greater equity in institutionally higher developed markets, and lower equity in those that are less developed. Hence, our first hypothesis is as follows:

H1. Formal institutional uncertainty level in the host country negatively affects the percentage of equity sought in a cross-border acquisition.

\subsection{Heterogeneous responses to institutional uncertainty}

A number of IB studies include firm market entry decisions as the dependent variable and institutional distance/development as the moderating variable (Dikova, 2012; Elango et al., 2013; Ilhan-Nas et al., 2018a; Ilhan-Nas et al., 2018b; Schwens et al., 2011; Zhang et al., 2014). While acknowledging that the theoretical focus of these studies is different than ours, we find some insightful guidance in these studies. For example, in a model with firm's market entry decision as the dependent variable, formal institutional distance/uncertainty has been shown to significantly interact with a range of variables such as the age and international experience of the CEO (Dikova, 2012), host country technology industry (Elango et al., 2013), board composition and family ownership (Ilhan-Nas et al., 2018a), ownership concentration (Ilhan-Nas et al., 2018b), firm's international experience, proprietary know-how, strategic importance (Schwens et al., 2011), and asset specificity (Zhang et al., 2014).

The literature recognizes that firms respond to institutional pressure in heterogeneous ways (Cui and Jiang, 2012; Kostova et al., 2008; Oliver, 1991). In line with this idea, Liou et al. (2017) find that the effect of formal institutional distance on the percentage of equity sought in cross border acquisitions is weaker for firms which are short of talented labor in their home countries. In other words, firms which are short of talented labor in their home countries seem to care less about the 
host country's institutional distance. Ando (2012) shows that the effect of formal institutional distance on the percentage of equity sought is reduced for firms with greater international experience, and also for firms with combined greater international experience and host-country experience. Likewise, Arslan and Dikova (2015) also confirm that the effect of formal institutional distance on the percentage of equity sought is weaker for firms with greater host-country experience.

\subsection{Legitimacy perspective of institutional theory}

The legitimacy perspective of institutional theory considers varied firm responses to institutional pressure resulting from legitimizing mechanisms that foreign firms pursue (Kostova et al., 2008). To be more specific, when multinationals face high institutional uncertainty, they try to gain legitimacy in order to avoid institutional pressure by local governments. In essence, multinationals seeking to enter foreign markets tend to engage in symbolic image-building. They may undertake a number of activities to bolster their image, one of which is associating themselves with other legitimate actors (Kostova and Zaheer, 1999). For example, a foreign firm could highlight its close links with its supplier firm which has already gained legitimacy in the host country, or publicize its controlling shareholders who have undertaken charity activities in the host country. Hence, by leveraging the positive image of other firms or actors, multinationals try to create positive perceptions about their own future activities. Foreign firms also pursue other activities which are not binding but are seen as socially desirable (such as CSR activities) to increase their legitimacy.

According to Kostova et al. (2008), diverse responses arise from these legitimizing mechanisms which are firm and institution specific. For example, in the presence of high institutional uncertainty, a negatively perceived firm might be able to gain limited legitimacy by actors in that country compared to a neutrally or positively perceived firm. Hence, owing to different levels of legitimacy gained by firms, there are heterogeneous responses to formal institutional distances. Generally, firms with rather limited legitimacy are under greater pressure to conform to institutional pressure as compared to firms which are able to gain relatively high legitimacy. Hence, in contrast to the classical institutional theory which assumes that all firms behave more or less in a similar way under institutional pressure, the legitimacy perspective of institutional theory recognizes that firms respond to institutional uncertainty in a somewhat heterogeneous way, depending on the amount of legitimacy gained.

\subsection{Formal institutional uncertainty in technological acquisitions}

In this study, we examined how firms responded to formal institutional uncertainty in cross-border acquisitions, specifically contrasting technology targets with those in other industries. From the legitimacy perspective of institutional theory, CBA bidders seeking technology firms are expected to experience greater institutional pressure due to their negative image in the host countries. The literature shows that when foreign firms approach local technology firms, host-country institutions rigorously safeguard their local technologies from diffusing abroad. As technology transfer is a major motivation in technology acquisitions, host country institutions are particularly concerned about the opportunistic behavior of foreign firms, and its possible negative effect on the local economy (Globerman and Shapiro, 2009). In other words, if acquirers seeking technology targets do not comply with institutional norms, host country governments are likely to take steps to prevent the target technology firms from being exploited. 
In this connection, Cui and Jiang (2012) found that state-owned Chinese firms experienced greater scrutiny by host country governments when taking over foreign targets. Consequently, they had to find ways, albeit limited, to gain legitimacy, while facing greater institutional uncertainty. For similar reasons, we expect that firms are more sensitive to formal institutional uncertainty when seeking technology targets compared to non-technology ones. We formulate our second hypothesis as follows:

$\mathrm{H} 2$ : The negative effect of host country formal institutional uncertainty on the percentage of equity sought is more pronounced for technology targets.

The conceptual model of our study is presented below in Figure 1.

Figure 1. The conceptual model

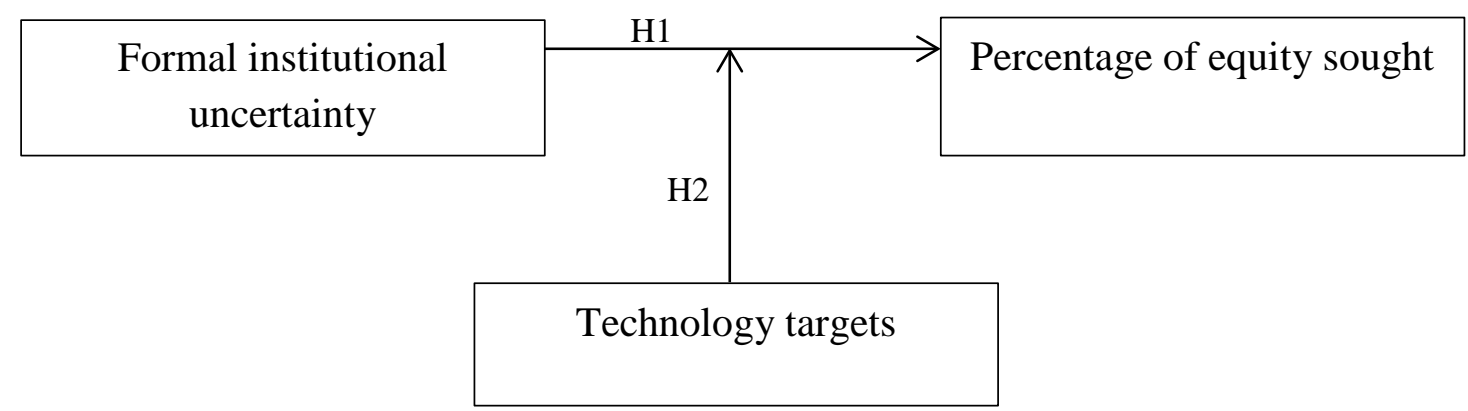

\section{Method}

\subsection{Acquisition deals}

We retrieved the data for acquisition deals from the Bloomberg database. Owing to our research design and the nature of control variables, we covered only the cross-border acquisitions undertaken by publicly-listed Japanese acquirers. Also, we shortlisted only those transactions in which the CBA bidder did not have any ownership in the target prior to the deal, and where the bidder ended up with at least $5 \%$ ownership after the completion of the deal. Furthermore, we focused only on completed transactions. Because of data limitations for control variables, we were restricted to a final sample of 1340 transactions that were announced between 2001-2018.

\subsection{Analytical model}

We ran the following model sequentially to test our hypotheses.

$$
\begin{aligned}
& \text { Percentage of equity sought } \\
& \qquad \begin{array}{l}
=\beta_{O}+\beta_{1}(\text { formal institutional uncertainty }) *(\text { technology target }) \\
+\beta_{2}(\text { formal institutional uncertainty })+\beta_{3}(\text { technology target }) \\
+\beta_{4}(\text { target size })+\beta_{5}(\text { acquirer size })+\beta_{6}(\text { acquirer experience }) \\
+\beta_{7}(\text { horizontal relatedness })+\beta_{8}(\text { cultural distance }) \\
+\beta_{9}(\text { host country size })+\beta_{10}(\text { year dummies })+\varepsilon
\end{array}
\end{aligned}
$$




\subsection{Dependent, independent, and moderating variables}

The dependent variable for our study was the percentage of equity sought in cross-border acquisitions. The data for this continuous variable were obtained from the Bloomberg database. As our dependent variable, viz. the percentage of equity sought, had an upper bound of $100 \%$, we conducted Tobit regression analysis because of its ability to consider censured dependent variables (Greene, 1993). Hence, our study is in line with the methodology of prior studies, with the percentage of equity sought as the outcome variable (Ahammad et al., 2017; Chari and Chang, 2009; Chikhouni et al., 2017; Cui and Jiang, 2012; Cuyper and Martin, 2006; Pan, 2002).

The independent variable of our primary interest was formal institutional uncertainty in the host countries. For this variable, we first averaged governance scores in each host country based on six dimensions of the Worldwide Governance Indicators: (1) Voice and accountability, (2) Political stability and lack of violence, (3) Government effectiveness, (4) Regulatory quality, (5) Rule of law, and (6) Control of corruption (Ahammad et al., 2017; Ang et al. 2015; Contractor et al., 2014; Hernández and Nieto, 2015; Lahiri et al., 2014). Second, rather than measuring the governance score of only one year prior to the deal announcement, we calculated the average governance scores of three years prior to the deal announcement. For example, for an acquisition announced in 2015, the average governance score was calculated for 3 years, i.e. 2012-2014. This operationalization took into consideration managers' decision-making trend over a longer time span rather than in a single year (Ahammad et al., 2017; Chari and Chang, 2009). Finally, for ease of interpretation, we reverse-coded the governance scores so that a higher score indicated greater uncertainty in the host country.

The moderating variable, technology target, was operationalized as a dummy variable which received the value of one for technology targets and zero for non-technology targets. To classify targets from the technology industry, we used the Bloomberg Industry Classification Systems (BISC) for which the technology sector includes four industry groups: (1) computers, (2) office/business equipment, (3) semiconductors, and (4) software. These groups have been included in hightechnology industry in prior studies as well (Certo et al., 2001; Elango et al., 2013; King et al., 2008; Walter et al., 2007). In unreported analyses, we further classified technology targets based on other sources in pharmaceuticals, aerospace, biotechnology, telecommunications, and electronics owing to their high R\&D intensity (NSF, 2019; OECD, 2011), and obtained consistent results.

\subsection{Control variables}

We controlled for several variables that had been identified in prior literature as important (Ahammed et al., 2017; Chari and Chang, 2009; Chikhouni et al., 2017). At the firm level, we included target size to control for its possible negative effect on our outcome variable (Chari and Chang, 2009). Following Ahammed et al. (2017), we operationalized target size as the natural logarithm of its market value, where market value was estimated as acquisition value/percentage of equity sought $\times 100$. Similarly, we controlled for acquirer size as the natural logarithm of total sales (Chikhouni et al., 2017; Chari and Chang, 2009; López-Duarte and García-Canal, 2002; 2004). Additionally, we controlled for acquirer experience by operationalizing it as the number of years since the acquirer's first acquisition in the host country (Chen, 2008; Chen and Hennart, 2004; Chikhouni et al., 2017; Mariotti et al., 2014). All these firm-level data were also obtained from the Bloomberg database. 
At the industry level, prior research controlled for the effect of horizontal relatedness between acquirers and targets by checking if both firms belonged to the same industry (Ang and Machialova, 2008; Chari and Chang, 2009; Contractor et al., 2014; Dang and Henry, 2016; Lahiri et al., 2014; Reuer and Koza, 2000; Vasedeva et al., 2018). In the same way, we operationalized horizontal relatedness as a dummy variable which received the value of one if acquirer and target belonged to the same thirdlevel industry classification as per BISC, and zero otherwise (Ahmed and Bebenroth, 2019; Waqar, 2020).

At the country level, we included two control variables. First, we controlled for the cultural distance between Japan and the host countries (Ahammad et al., 2017; Contractor et al., 2014; Chari and Chang, 2009). Following prior studies, we measured cultural distance by Kogut and Singh's (1988) composite index based upon Hofstede's (1980) four cultural dimensions (Arslan and Wang, 2015; Demirbag et al., 2007; Dow et al., 2016; Lahiri et al., 2014; Liang et al., 2009; Vasedeva et al., 2018). The data for this variable were obtained from Hofstede et al. (2010). Second, we controlled for host country size by operationalizing it as the natural logarithm of host country GDP (Liang et al., 2009). We measured this variable based on a three-year average prior to the deal announcement. The data for this variable were obtained from the World Bank.

Finally, as the data were from multiple years, we included year dummies in the regression analysis. Definitions, references, and data sources for all variables are shown in Table I. 
Table I. Summary of variables

\begin{tabular}{|c|c|c|c|}
\hline Variables & Definitions & References & $\begin{array}{l}\text { Data } \\
\text { Sources }\end{array}$ \\
\hline $\begin{array}{l}\text { Percentage of } \\
\text { equity sought }\end{array}$ & $\begin{array}{l}\text { A continuous variable which represents the percentage } \\
\text { of equity sought by the acquirer in cross-border } \\
\text { acquisitions. }\end{array}$ & $\begin{array}{l}\text { Ahammad et al. (2017); Chari } \\
\text { and Chang (2009); Chikhouni } \\
\text { et al. (2017) }\end{array}$ & $\begin{array}{c}\text { Bloomberg } \\
\text { data }\end{array}$ \\
\hline $\begin{array}{l}\text { Formal } \\
\text { institutional } \\
\text { uncertainty }\end{array}$ & $\begin{array}{l}\text { Reverse-coded governance score of the host countries } \\
\text { based upon three years average prior to the deal } \\
\text { announcement. The average governance scores in each } \\
\text { host country is based on six dimensions of Worldwide } \\
\text { Governance Indicators: (1) Voice and accountability, } \\
\text { (2) Political stability and lack of violence, (3) } \\
\text { Government effectiveness, (4) Regulatory quality, (5) } \\
\text { Rule of law, and (6) Control of corruption. }\end{array}$ & Ahammad et al. (2017) & $\begin{array}{l}\text { World Bank } \\
\text { Data }\end{array}$ \\
\hline $\begin{array}{l}\text { Technology } \\
\text { targets }\end{array}$ & $\begin{array}{l}\text { A dummy variable which receives a value of one for } \\
\text { technology targets and zero for non-technology targets. }\end{array}$ & $\begin{array}{l}\text { Certo et al. (2001); Elango et } \\
\text { al. (2013); King et al. (2008); } \\
\quad \text { Walter et al. (2007) }\end{array}$ & $\begin{array}{c}\text { Bloomberg } \\
\text { data }\end{array}$ \\
\hline $\begin{array}{l}\text { Acquirer } \\
\text { experience }\end{array}$ & $\begin{array}{l}\text { Number of years since the first acquisition in the target } \\
\text { country. }\end{array}$ & $\begin{array}{l}\text { Arslan and Wang (2015); Chen } \\
\text { and Hennart (2004); Chen } \\
\text { (2008); Chikhouni et al. (2017); } \\
\text { Mariotti et al. (2014) }\end{array}$ & $\begin{array}{c}\text { Bloomberg } \\
\text { data }\end{array}$ \\
\hline Acquirer size & Natural logarithm of total sales. & $\begin{array}{l}\text { Chikhouni et al., 2017; Chari } \\
\text { and Chang, 2009; Lopes Duarte } \\
\text { and Garcia-Canal, 2002; } 2004\end{array}$ & $\begin{array}{c}\text { Bloomberg } \\
\text { data }\end{array}$ \\
\hline Target size & $\begin{array}{c}\text { Natural logarithm of the market value, where market } \\
\text { value is estimated as acquisition value/percentage of } \\
\text { equity sought } \times 100 \text {. }\end{array}$ & Ahammad et al. (2017) & $\begin{array}{c}\text { Bloomberg } \\
\text { data }\end{array}$ \\
\hline $\begin{array}{l}\text { Horizontal } \\
\text { relatedness }\end{array}$ & $\begin{array}{l}\text { Dummy variable which takes the value of one if } \\
\text { acquirer and target are from same third level industry } \\
\text { (as per BICS), and zero otherwise. }\end{array}$ & $\begin{array}{l}\text { Ahmed and Bebenroth (2019); } \\
\text { Ang and Machialova (2008); } \\
\text { Chari and Chang (2009); } \\
\text { Contractor et al. (2014); Dang } \\
\text { and Henry (2016); Lahiri et al. } \\
\text { (2014); Reuer and Koza (2000); } \\
\text { Vasedeva et al. (2018); Waqar } \\
\text { (2020) }\end{array}$ & $\begin{array}{c}\text { Bloomberg } \\
\text { data }\end{array}$ \\
\hline $\begin{array}{l}\text { Cultural } \\
\text { distance }\end{array}$ & $\begin{array}{c}\text { Kogut and Singh (1988) composite index for the } \\
\text { difference between Japan and host country culture } \\
\text { based on four dimensions of Hofstede (1980). These } \\
\text { dimensions are (1) individualism-collectivism, (2) } \\
\text { power distance, (3) uncertainty avoidance, and (4) } \\
\text { masculinity-femininity }\end{array}$ & $\begin{array}{l}\text { Arslan and Wang (2015); } \\
\text { Demirbag et al. (2007); Dow et } \\
\text { al., 2016; Lahiri et al. (2014); } \\
\text { Liang et al. (2009); Vasedeva et } \\
\text { al. (2018) }\end{array}$ & $\begin{array}{l}\text { Hofstede et } \\
\text { al. (2010) }\end{array}$ \\
\hline $\begin{array}{l}\text { Host country } \\
\text { size }\end{array}$ & $\begin{array}{l}\text { Natural logarithm of host country GDP based on the } \\
\text { average of three years prior to the deal announcement. }\end{array}$ & Liang et al. (2009) & $\begin{array}{l}\text { World Bank } \\
\text { Data }\end{array}$ \\
\hline
\end{tabular}




\section{Results}

\subsection{Descriptive statistics}

We report the descriptive statistics and correlation matrix of our sample of 1340 observations including 116 technology acquisitions in Table II. We checked the variance inflation factors (VIFs) for these variables and found that the highest VIF value was 1.47 , showing absence of any multicollinearity issue. We centered all continuous variables before using them in the regression analysis.

Table II. Descriptive statistics and correlation matrix

\begin{tabular}{|c|c|c|c|c|c|c|c|c|c|c|c|}
\hline & & Mean & S.D. & (1) & $(2)$ & (3) & (4) & (5) & (6) & (7) & $(8)$ \\
\hline (1) & Percentage of equity sought & 66.70 & 36.22 & & & & & & & & \\
\hline (2) & Technology target & 0.09 & 0.28 & $-0.34 * * *$ & & & & & & & \\
\hline (3) & Formal institutional uncertainty & -0.88 & 0.77 & $0.08 * * *$ & $-0.07^{* * *}$ & & & & & & \\
\hline (4) & Acquirer experience & 6.10 & 5.80 & $-0.09 * * *$ & $-0.14^{* * *}$ & $-0.05^{* *}$ & & & & & \\
\hline (5) & Acquirer size & 21.89 & 2.33 & $-0.10^{* * *}$ & -0.01 & -0.02 & $0.57^{* * *}$ & & & & \\
\hline (6) & Target size & 17.96 & 2.43 & -0.03 & $-0.09 * * *$ & 0.02 & $0.43^{* * *}$ & $0.56 * * *$ & & & \\
\hline (7) & Horizontal relatedness & 0.28 & 0.45 & $0.05 *$ & $0.07^{* *}$ & $-0.06^{* *}$ & $-0.07 * *$ & $-0.14 * * *$ & $-0.21^{* * *}$ & & \\
\hline (8) & Cultural distance & 3.04 & 1.14 & $-0.08 * * *$ & $-0.09^{* * *}$ & 0.01 & $-0.05^{*}$ & -0.02 & -0.03 & 0.00 & \\
\hline (9) & Host country size & 28.11 & 1.62 & $0.34 * * *$ & $-0.25^{* * *}$ & 0.04 & $0.11^{* * *}$ & -0.03 & $0.10^{* * *}$ & -0.04 & $-0.37^{* * *}$ \\
\hline
\end{tabular}

Note: $N=1340$ observations. ***,**,* represent statistical significance at $1 \%, 5 \%$, and $10 \%$ respectively. 


\subsection{Tobit regression analysis}

The results are reported in Table III. In Model 1, we included only control variables which explained $16.54 \%$ variation in the dependent variable. As our continuous dependent variable represented percentage of equity sought in an acquisition deal, the significant and negative coefficient of target size $(p<0.01)$ implied that the acquirer tended to choose lower equity for larger targets. Similarly, the positive and significant coefficient of horizontal relatedness $(p<0.1)$ implied that acquirer tended to choose greater equity in horizontally related target industries.

In Model 2, the coefficient of formal institutional uncertainty was significant and negative ( $p<$ $0.01)$, supporting Hypothesis 1 . The significant and negative interaction term in Model $3(p<0.05)$ implied that the negative effect of formal institutional uncertainty on the percentage of equity sought was more pronounced for technology targets. Hence, Hypothesis 2 was also supported. For a better interpretation of the results of Hypothesis 2, we present the interaction plot in Figure 2, showing that the line for technology targets is steeper than that for non-technology firms.

Table III. Tobit regression analysis

\begin{tabular}{|c|c|c|c|}
\hline & Model 1 & Model 2 & Model 3 \\
\hline $\begin{array}{l}\text { Formal institutional uncertainty * } \\
\text { Technology target }\end{array}$ & & & $\begin{array}{l}-16.80 * * \\
(7.97)\end{array}$ \\
\hline Formal institutional uncertainty & & $\begin{array}{l}-23.72 * * * \\
(2.11)\end{array}$ & $\begin{array}{l}-22.50 * * * \\
(2.18)\end{array}$ \\
\hline Technology target & & $\begin{array}{l}13.97^{* *} \\
(5.73)\end{array}$ & $\begin{array}{l}12.78^{* *} \\
(5.86)\end{array}$ \\
\hline Target size & $\begin{array}{l}-2.25^{* * *} \\
(0.84)\end{array}$ & $\begin{array}{l}-3.44^{* * *} \\
(0.81)\end{array}$ & $\begin{array}{l}-3.38^{* * *} \\
(0.81)\end{array}$ \\
\hline Acquirer size & $\begin{array}{r}1.21 \\
(1.01)\end{array}$ & $\begin{array}{l}2.39 * * \\
(0.96)\end{array}$ & $\begin{array}{l}2.20^{* *} \\
(0.96)\end{array}$ \\
\hline Acquirer experience & $\begin{array}{l}-0.70^{*} \\
(0.41)\end{array}$ & $\begin{array}{l}-1.14^{* * *} \\
(0.39)\end{array}$ & $\begin{array}{l}-1.11 * * * \\
(0.39)\end{array}$ \\
\hline Horizontal relatedness & $\begin{array}{l}6.69 * \\
(3.74)\end{array}$ & $\begin{array}{l}10.22 * * * \\
(3.57)\end{array}$ & $\begin{array}{l}10.51^{* * *} \\
(3.57)\end{array}$ \\
\hline Cultural distance & $\begin{array}{l}3.03^{* * *} \\
(1.49)\end{array}$ & $\begin{array}{r}-0.64 \\
(1.45)\end{array}$ & $\begin{array}{r}-0.64 \\
(1.46)\end{array}$ \\
\hline Host country size & $\begin{array}{l}15.42^{* * *} \\
(1.13)\end{array}$ & $\begin{array}{l}11.59 * * * \\
(1.11)\end{array}$ & $\begin{array}{l}11.64^{* * *} \\
(1.11)\end{array}$ \\
\hline Intercept & $\begin{array}{l}81.28 * * * \\
(10.22)\end{array}$ & $\begin{array}{l}66.20^{* * *} \\
(9.80)\end{array}$ & $\begin{array}{l}66.50 * * * \\
(9.79)\end{array}$ \\
\hline Year fixed effects & Yes & Yes & Yes \\
\hline Sample size & 1340 & 1340 & 1340 \\
\hline Pseudo R-squared & $16.54 \%$ & $24.55 \%$ & $24.81 \%$ \\
\hline Log likelihood & -4355.16 & -4287.08 & -4284.88 \\
\hline
\end{tabular}

Notes: The dependent variable for these Tobit regression models is the percentage of equity sought in cross-border acquisitions. Standard errors are reported in the parenthesis. ${ }^{* * *},{ }^{* *},{ }^{*}$ represent statistical significance at $1 \%, 5 \%$, and $10 \%$ respectively. 
Figure 2. Interaction plot

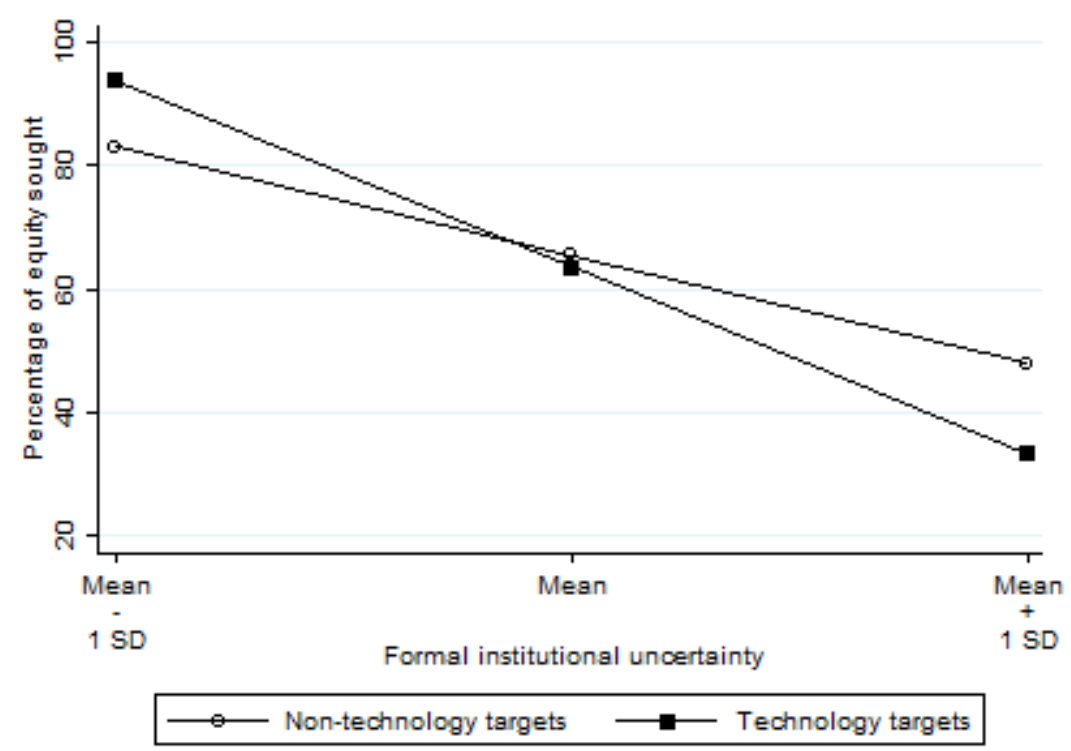

\section{Robustness Check}

We conducted a number of robustness checks in addition to our main analysis. Many studies have considered firm entry mode decision as a binary choice in which partial acquisitions are compared with full or majority acquisitions. As part of such investigations, some scholars have used a relatively high cut-off, such as 95\% (Vasudeva et al., 2018; Cui and Jiang, 2012). In contrast, others have acknowledged that relatively low cut-offs, such as 50\%, also matter (Dang and Henry, 2016; Demirbag et al., 2007). While embracing the benefits of using these specific cut-offs, we opted for a more robust methodology used by Chen (2008), in which a number of cut-offs were analyzed to contrast partial versus full/majority acquisitions. Therefore, we considered four cut-offs with 20 percentage point differences: $95 \%, 75 \%, 55 \%$, and $35 \%$.

The results of these robustness checks are shown in Table IV. In line with prior studies, we conducted logistic regression analysis for our binary outcome variable (Arslan and Wang, 2015; Chen, 2008; Chen and Hennart, 2004; Liang et al., 2009). In Panel A, all transactions with percentage of equity sought less than or equal to $95 \%$ were classified as partial acquisitions, while all transactions with greater than $95 \%$ represented full acquisitions. In the same way, the cut-off of $75 \%, 55 \%$, and $35 \%$ were applied in Panel B, Panel C, and Panel D, respectively. Throughout Table IV, partial acquisition was the reference category of our dichotomous dependent variables.

Table IV shows that Hypothesis 1 was supported for all four cut-offs, while Hypothesis 2 received support for 3 out of 4 cut-offs. It also lent support to Dang and Henry's (2016) advice that studies need to be cautious in their binary classification of partial versus full acquisitions. It must also be mentioned that stock exchange regulations in some countries mandate a delisting of firms if the ownership of the largest shareholder exceeds a certain cutoff. In fact, Dang and Henry (2016) mention cut-off values of certain countries ranging from $80 \%$ to $95 \%$. Hence, in a country with cut-off value of $80 \%$, a deal with 
even $81 \%$ would be classified as full acquisition. As such, in future studies, multiple cut-offs for a comprehensive interpretation of their findings should be considered. Overall, our results were quite robust to these alternative ways of operationalizing our dependent variable.

Table IV. Logistic regression analysis

\begin{tabular}{|c|c|c|c|}
\hline \multicolumn{4}{|c|}{ Panel A: Partial acquisition $\leq \mathbf{9 5 \%}$} \\
\hline & Model 1 & Model 2 & Model 3 \\
\hline $\begin{array}{l}\text { Formal institutional uncertainty * } \\
\text { Technology target }\end{array}$ & & & $\begin{array}{l}-0.45 \\
(0.39)\end{array}$ \\
\hline Formal institutional uncertainty & & $\begin{array}{l}-1.02 * * * \\
(0.10)\end{array}$ & $\begin{array}{l}-0.99 * * * \\
(0.10)\end{array}$ \\
\hline Technology target & No & Yes & Yes \\
\hline Controls & Yes & Yes & Yes \\
\hline Pseudo R-squared & $18.59 \%$ & $29.59 \%$ & $29.70 \%$ \\
\hline
\end{tabular}

Panel B: Partial acquisition $\leq 75 \%$

\begin{tabular}{|c|c|c|c|}
\hline \multirow[b]{2}{*}{$\begin{array}{l}\text { Formal institutional uncertainty * } \\
\text { Technology target }\end{array}$} & Model 1 & Model 2 & Model 3 \\
\hline & & & $\begin{array}{l}-0.71^{*} \\
(0.39)\end{array}$ \\
\hline \multicolumn{2}{|l|}{ Formal institutional uncertainty } & $\begin{array}{l}-1.05 * * * \\
(0.09)\end{array}$ & $\begin{array}{l}-1.00 * * * \\
(0.10)\end{array}$ \\
\hline Technology target & No & Yes & Yes \\
\hline Controls & Yes & Yes & Yes \\
\hline Pseudo R-squared & $19.78 \%$ & $31.89 \%$ & $32.18 \%$ \\
\hline \multicolumn{4}{|c|}{ Panel C: Partial acquisition $\leq 55 \%$} \\
\hline \multirow{2}{*}{\multicolumn{2}{|c|}{$\begin{array}{l}\text { Formal institutional uncertainty * } \\
\text { Technology target }\end{array}$}} & Model 2 & Model 3 \\
\hline & & & $\begin{array}{l}-0.67 * \\
(0.35)\end{array}$ \\
\hline \multicolumn{2}{|l|}{ Formal institutional uncertainty } & $\begin{array}{l}-0.89 * * * \\
(0.09)\end{array}$ & $\begin{array}{l}-0.85 * * * \\
(0.09)\end{array}$ \\
\hline Technology target & No & Yes & Yes \\
\hline Controls & Yes & Yes & Yes \\
\hline Pseudo R-squared & $19.63 \%$ & $29.01 \%$ & $29.31 \%$ \\
\hline \multicolumn{4}{|c|}{ Panel D: Partial acquisition $\leq 35 \%$} \\
\hline \multirow[b]{2}{*}{$\begin{array}{l}\text { Formal institutional uncertainty * } \\
\text { Technology target }\end{array}$} & Model 1 & Model 2 & Model 3 \\
\hline & & & $\begin{array}{l}-0.58 * \\
(0.35)\end{array}$ \\
\hline Formal institutional uncertainty & & $\begin{array}{l}-0.68 * * * \\
(0.09)\end{array}$ & $\begin{array}{l}-0.64 * * * \\
(0.09)\end{array}$ \\
\hline Technology target & No & Yes & Yes \\
\hline Controls & Yes & Yes & Yes \\
\hline Pseudo R-squared & $21.19 \%$ & $26.41 \%$ & $26.90 \%$ \\
\hline \multicolumn{4}{|c|}{$\begin{array}{l}\text { Notes: The binary dependent variable for these logistic regression models takes the value of } 0 \text { for partial } \\
\text { acquisitions, and } 1 \text { for majority/full acquisitions. Control variables, year dummies and intercept are } \\
\text { included in the regressions but have not been reported for the sake of brevity. }{ }^{* * *} \text {, *** represent } \\
\text { statistical significance at } 1 \%, 5 \% \text {, and } 10 \% \text { respectively. } N=1340 \text { observations. }\end{array}$} \\
\hline
\end{tabular}




\section{Discussion}

In this study, we focused on the interplay between the level of host country institutional uncertainty and the equity sought in cross-border acquisitions, comparing targets from the technology versus those from the non-technology industry. We tested two hypotheses on a sample of 1340 deals undertaken by Japanese firms: (1) direct effect of host country formal institutional uncertainty on the equity sought, and (2) moderating influence of technology industry on the relationship between formal institutional uncertainty and equity sought. We discuss below our results in the light of prior literature.

First, corroborating a number of previous studies, we found that Japanese firms preferred lower equity participation in targets in institutionally less developed host countries. This finding is supported by Delios and Beamish (1999) who found that host country restrictiveness led Japanese firms to choose lower equity in their targets located in nine East and South-East Asian countries. Yiu and Makino (2002) note that generally Japanese firms prefer joint ventures over wholly owned subsidiaries in host countries with more restrictive regulatory environments. Hence, our finding supports the view that joining a local partner in a regulation-wise restrictive host country allows the acquiring firm to lessen its liability of foreignness. Similarly, based on a sample of 2399 observations, Xu et al. (2004) found that large institutional distance (regulative and normative) led Japanese firms to choose a lower equity level in cross-border acquisitions. Likewise, based on a sample of foreign subsidiaries established in Turkey, Demirbag et al. (2007) noted that foreign firms avoided wholly owned subsidiaries when facing higher differences in the corruption index between Turkey and their home countries. In the same way, Chari and Chang (2009) showed that when US firms undertook crossborder acquisitions in countries with higher risk (measured by the International Country Risk Guide), they chose a lower equity position in the target firms (ICRG, 2019).

Second, we found support for $\mathrm{H} 2$ related to host country formal institutional uncertainty with regard to technology targets. By building upon the legitimacy perspective of institutional theory (Kostova et al., 2008), we show that acquirers who sought technology targets were more sensitive than acquirers of targets in other industries. That could be due to their negative image in the host country. Thus, our findings support Kostova and Zaheer's (1999) argument that the legitimation process is, indeed, complex. In their conceptual paper, the authors contended that host country stakeholders are usually equipped with limited information about foreign firms, in contrast to domestic firms. Hence, host country stakeholders tend to make stereotypical judgements about foreign firms by classifying them into certain groups. While cross-border bidders are often perceived negatively because of their foreignness, MNEs belonging to a certain geographical region or "industry" may face an even stronger resistance (Kostova and Zaheer, 1999: 74). In other words, the legitimation process is marked with spillover effects such that the negative image attached to a certain group of organizations (based on geographical region or industry) affects the legitimacy of other firms which are perceived to be part of that group. For example, if one specific cross-border investor exploits the agricultural sector in a given host country, other firms also seeking to enter the agricultural sector may automatically be perceived negatively by the host country actors based on negative experiences with the earlier cross-border investor. Similarly, in the context of our study, we argue that as the underlying reason for the acquisition of technology firms is often the transfer of technology back to the home country, foreign acquirers seeking technology targets face difficulty in gaining legitimacy. Host country 
actors are rather protective of local technology and would take steps to prevent it from diffusing abroad.

Cui and Jiang (2012) also applied the legitimacy perspective of institutional theory to investigate moderating influences of (Chinese) foreign firms' state ownership on the relationship between host country institutional pressure and market entry choice. In contrast, we advance the legitimacy perspective of institutional theory by comparing technology targets to non-technology ones. Our results somehow contradict those of Elango et al. (2013) who found that firms would rather fully acquire technology targets at a higher formal institutional distance. However, as their study focused on acquisitions made in four major emerging economies, they rationalized their findings by suggesting that when multinationals from developed countries buy technology firms in institutionally underdeveloped countries, they aim for a greater control over the target "to protect their newly acquired technology in an unfamiliar institutional setting" (Elango et al., 2013: 513). In contrast, our analysis of Japanese outbound acquisitions supports the legitimacy perspective of institutional theory on the assumption that acquirers are more cautious when seeking technology firms.

In view of the foregoing, we therefore lend support to the strand of literature which emphasizes that in cross-border deals, industry does matter (Datta et al., 2005; Kim, 2018; Rajagopalan and Datta, 1996; Singal, 2014; Su, 2015; Perrons and Platts, 2005; Yang et al., 2007). Prior research has shown that industry is an important variable affecting CEO characteristics (Rajagopalan and Datta, 1996), organizational learning (Weerawardena et al., 2006) and patent registration (Kim, 2018). There is further literature on capital markets (Merkley et al., 2017), stakeholder management (Griffin and Koerber, 2006), labor productivity (Datta et al., 2005) and earnings management (He and Yang, 2014). In line with these studies, our investigation finds that the effect of host country formal institutional uncertainty on the percentage of equity sought in cross border acquisitions is, indeed, moderated by the nature of the industry, and in this study our focus is on technology targets.

\section{Limitations and future research avenues}

Like any other study, this study is not without its limitations. First, our analysis was based only on the data from Japanese firms, limiting the generalizability of our findings. Even if the authors did not find any convincing reason to worry about including only Japanese firms, future research could still consider multi-country acquirers and targets design to confirm the generalizability. Second, we measured institutional uncertainty, as many other studies did, by relying on secondary data sources (Dikova et al. 2010; Ilhan-Nas et al., 2018a; Ilhan-Nas et al., 2018b; Liou et al., 2016; Liou et al., 2017; Yiu and Makino,2002).

In line with many other studies (Ahammad et al., 2017; Ang et al. 2015; Contractor et al., 2014; Hernández and Nieto, 2015; Lahiri et al., 2014), and because of its accessibility, we chose the Worldwide Governance Indicator to measure formal institutional uncertainty. Future research could also use a survey-based approach to take advantage of perceptual measures. Decision-makers' views of their environment could be investigated because it is the decision-makers' perception of the reality - rather than the reality itself - that affects the decision (Cui and Jiang, 2012; Santangelo and Meyer, 2011). Likewise, we resorted to the Bloomberg Industry Classification Systems (BICS) for the classification of technology industry sector whereas Standard Industry Classification (SIC) has been used more often in prior studies (Certo et al., 2001; Elango et al., 2013; Hagedoorn and Duysters, 2002; 
King et al., 2008; Walter et al., 2008). We admit that it makes comparisons to other studies difficult. However, we argue that SIC coding to classify technology firms has not been applied consistently in prior studies. Nonetheless, in future, scholars could replicate our study using SIC-based classification coding for a comparison with our results.

Despite such limitations, this study has shown a moderating effect of technology targets on the relationship between formal institutional uncertainty and the percentage of equity sought. It is hoped that it might inspire more future research on industry heterogeneity. 


\section{References}

Ahammad, M.F., Leone, V., Tarba, S.Y., Glaister, K.W. and Arslan, A., 2017. Equity ownership in crossborder mergers and acquisitions by British firms: An analysis of real options and transaction cost factors. British Journal of Management, 28(2), pp.180-196.

Ahmed, K. and Bebenroth, R. (2019). Acquisition behavior of emerging versus developed market multinationals. Organizations and Markets in Emerging Economies, 10(1), 9-30, https://doi.org/10.15388/omee.2019.10.00001

Ando, N., 2012. The ownership structure of foreign subsidiaries and the effect of institutional distance: a case study of Japanese firms. Asia Pacific business review, 18(2), pp.259-274.

Ang, S.H. and Michailova, S., 2008. Institutional explanations of cross-border alliance modes: The case of emerging economies firms. Management International Review, 48(5), pp.551-576.

Ang, S.H., Benischke, M.H. and Doh, J.P., 2015. The interactions of institutions on foreign market entry mode. Strategic Management Journal, 36(10), pp.1536-1553.

Arslan, A. and Dikova, D., 2015. Influences of institutional distance and MNEs' host country experience on the ownership strategy in cross-border M\&As in emerging economies. Journal of Transnational Management, 20(4), pp.231-256.

Arslan, A., and Wang, Y. (2015). Acquisition entry strategy of Nordic multinational enterprises in China: An analysis of key determinants. Journal of Global Marketing, 28(1), 32-51.

Beamish, B., Pan, W. and Xu, Y., 2004. D. The effect of regulative and normative distances on MNE ownership. Management International Review, 44(3). 285-307.

Brouthers, K.D. and Hennart, J.F., 2007. Boundaries of the firm: Insights from international entry mode research. Journal of Management, 33(3), pp.395-425.

Certo, S.T., Covin, J.G., Daily, C.M. and Dalton, D.R., 2001. Wealth and the effects of founder management among IPO-stage new ventures. Strategic management journal, 22(6-7), pp.641-658.

Chari, M.D. and Chang, K., 2009. Determinants of the share of equity sought in cross-border acquisitions. Journal of International Business Studies, 40(8), pp.1277-1297.

Chen, S.F.S. and Hennart, J.F., 2004. A hostage theory of joint ventures: why do Japanese investors choose partial over full acquisitions to enter the United States? Journal of Business Research, 57(10), pp.1126-1134.

Chen, S.F.S., 2008. The motives for international acquisitions: Capability procurements, strategic considerations, and the role of ownership structures. Journal of International Business Studies, 39(3), pp.454-471.

Chikhouni, A., Edwards, G. and Farashahi, M., 2017. Psychic distance and ownership in acquisitions: Direction matters. Journal of International Management, 23(1), pp.32-42.

Contractor, F.J., Lahiri, S., Elango, B. and Kundu, S.K., 2014. Institutional, cultural and industry related determinants of ownership choices in emerging market FDI acquisitions. International Business Review, 23(5), pp.931-941.

Cui, L. and Jiang, F., 2012. State ownership effect on firms' FDI ownership decisions under institutional pressure: A study of Chinese outward-investing firms. Journal of international business studies, 43(3), pp.264-284.

Cuypers, I.R. and Martin, X., 2010. What makes and what does not make a real option? A study of equity shares in international joint ventures. Journal of International Business Studies, 41(1), pp.47-69.

Dang, M. and Henry, D., 2016. Partial-control versus full-control acquisitions: Does target corporate governance matter? Evidence from eight East and Southeast Asian countries. Pacific-Basin Finance Journal, 40, pp.251-265.

Datta, D.K., Guthrie, J.P. and Wright, P.M., 2005. Human resource management and labor productivity: does industry matter? Academy of management Journal, 48(1), pp.135-145. 
Delios, A. and Beamish, P.W., 1999. Ownership strategy of Japanese firms: Transactional, institutional, and experience influences. Strategic management journal, 20(10), pp.915-933.

Demirbag, M., Glaister, K. W., and Tatoglu, E. (2007). Institutional and transaction cost influences on MNEs' ownership strategies of their affiliates: Evidence from an emerging market. Journal of World Business, 42(4), 418-434.

Dikova, D., 2012. Entry mode choices in transition economies: The moderating effect of institutional distance on managers' personal experiences. Journal of East-West Business, 18(1), pp.1-27.

Dikova, D., Sahib, P.R. and Van Witteloostuijn, A., 2010. Cross-border acquisition abandonment and completion: The effect of institutional differences and organizational learning in the international business service industry, 1981-2001. Journal of International Business Studies, 41(2), pp.223-245.

DiMaggio, P.J. and Powell, W.W., 1983. The iron cage revisited: Institutional isomorphism and collective rationality in organizational fields. American sociological review, pp.147-160.

Dow, D., Cuypers, I.R. and Ertug, G., 2016. The effects of within-country linguistic and religious diversity on foreign acquisitions. Journal of International Business Studies, 47(3), pp.319-346.

Elango, B., Lahiri, S., \& Kundu, S. K. (2013). How does firm experience and institutional distance impact ownership choice in high-technology acquisitions? R\&D Management, 43(5), 501-516.

Globerman, S., \& Shapiro, D. (2009). Economic and strategic considerations surrounding Chinese FDI in the United States. Asia Pacific Journal of Management, 26(1), 163-183.

Goodrick, E. and Salancik, G.R., 1996. Organizational discretion in responding to institutional practices: Hospitals and cesarean births. Administrative science quarterly, pp.1-28.

Graebner, M.E., Eisenhardt, K.M. and Roundy, P.T., 2010. Success and failure in technology acquisitions: Lessons for buyers and sellers. Academy of management perspectives, 24(3), pp.7392.

Greene, W.H. 1993. Econometric analysis, (2nd ed.). New York: Macmillan.

Griffin, J. J., \& Koerber, C. P. (2006, August). Does industry matter when managing stakeholder relations? In Academy of Management Proceedings (Vol. 2006, No. 1, pp. G1-G6). Briarcliff Manor, NY 10510: Academy of Management.

Hagedoorn, J. and Duysters, G., 2002. External sources of innovative capabilities: the preferences for strategic alliances or mergers and acquisitions. Journal of management studies, 39(2), pp.167-188.

$\mathrm{He}$, L. and Yang, R., 2014. Does industry regulation matter? New evidence on audit committees and earnings management. Journal of Business Ethics, 123(4), pp.573-589.

Hernández, V. and Nieto, M.J., 2015. The effect of the magnitude and direction of institutional distance on the choice of international entry modes. Journal of World Business, 50(1), pp.122-132.

Hofstede, G. (1980). Culture and organizations. International Studies of Management \& Organization, 10(4), 15-41.

Hofstede, G. H., Hofstede, G. J., and Minkov, M. (2010). Cultures and organizations: Software of the mind. New York: McGraw-Hill.

ICRG, 2019. The International Country Risk Guide (ICRG), The PRS Group, viewed 25 June 2019, https://www.prsgroup.com/explore-our-products/international-country-risk-guide.

Ilhan-Nas, T., Okan, T., Tatoglu, E., Demirbag, M. and Glaister, K.W., 2018b. The effects of ownership concentration and institutional distance on the foreign entry ownership strategy of Turkish MNEs. Journal of Business Research, 93, pp.173-183.

Ilhan-Nas, T., Okan, T., Tatoglu, E., Demirbag, M., Wood, G. and Glaister, K.W., 2018a. Board composition, family ownership, institutional distance and the foreign equity ownership strategies of Turkish MNEs. Journal of World Business, 53(6), pp.862-879.

Kim, K., 2018. Diminishing Returns to R\&D investment on innovation in manufacturing SMEs: do the technological intensity of industry matter? International Journal of Innovation Management, 22(07), p.1850056.

King, D.R., Slotegraaf, R.J. and Kesner, I., 2008. Performance implications of firm resource interactions in the acquisition of R\&D-intensive firms. Organization science, 19(2), pp.327-340. 
Kogut, B. and Singh, H., 1988. The effect of national culture on the choice of entry mode. Journal of international business studies, 19(3), pp.411-432.

Kostova, T. and Zaheer, S., 1999. Organizational legitimacy under conditions of complexity: The case of the multinational enterprise. Academy of Management review, 24(1), pp.64-81.

Kostova, T., Roth, K. and Dacin, M.T., 2008. Institutional theory in the study of multinational corporations: A critique and new directions. Academy of management review, 33(4), pp.994-1006.

Lahiri, S., Elango, B. and Kundu, S.K., 2014. Cross-border acquisition in services: Comparing ownership choice of developed and emerging economy MNEs in India. Journal of World Business, 49(3), pp.409-420.

Liang, X., Musteen, M., and Datta, D. K. (2009). Strategic orientation and the choice of foreign market entry mode: an empirical examination. MIR: Management International Review, 269-290.

Liou, R.S., Chao, M.C.H. and Ellstrand, A., 2017. Unpacking Institutional Distance: Addressing Human Capital Development and Emerging-Market Firms' Ownership Strategy in an Advanced Economy. Thunderbird International Business Review, 59(3), pp.281-295.

Liou, R.S., Chao, M.C.H. and Yang, M., 2016. Emerging economies and institutional quality: Assessing the differential effects of institutional distances on ownership strategy. Journal of World Business, 51(4), pp.600-611.

López-Duarte, C. and García-Canal, E., 2002. Adverse selection and the choice between joint ventures and acquisitions: Evidence from Spanish firms. Journal of Institutional and Theoretical Economics JITE, 158(2), pp.304-324.

López-Duarte, C. and García-Canal, E., 2004. The choice between joint ventures and acquisitions in foreign direct investments: The role of partial acquisitions and accrued experience. Thunderbird International Business Review, 46(1), pp.39-58.

Mariotti, S., Piscitello, L. and Elia, S., 2014. Local externalities and ownership choices in foreign acquisitions by multinational enterprises. Economic Geography, 90(2), pp.187-211.

Merkley, K., Michaely, R. and Pacelli, J., 2017. Does the scope of the sell-side analyst industry matter? An examination of bias, accuracy, and information content of analyst reports. The Journal of Finance, 72(3), pp.1285-1334.

Meyer, K.E., Estrin, S., Bhaumik, S.K. and Peng, M.W., 2009. Institutions, resources, and entry strategies in emerging economies. Strategic management journal, 30(1), pp.61-80.

North, D. 1990. Institutions, institutional change and economic performance. Cambridge: Cambridge University Press.

National Science Foundation (NSF), 2018. Industry, technology, and the global marketplace. National Science Board, Science \& Engineering Indicators, viewed 21 December 2019, https://www.nsf.gov/statistics/2018/nsb20181/assets/1235/industry-technology-and-theglobal-marketplace.pdf

OECD, 2011. ISIC Rev. 3 Technology Intensity Definition. OECD Directorate for Science, Technology and Industry Economic Analysis and Statistics Division, viewed 21 December 2019, https://www.oecd.org/sti/ind/48350231.pdf.

Oguji, N. and Owusu, R.A., 2017. Acquisitions entry strategies in Africa: the role of institutions, targetspecific experience, and host-country capabilities - the case acquisitions of Finnish multinationals in Africa. Thunderbird International Business Review, 59(2), pp.209-225.

Oliver, C., 1991. Strategic responses to institutional processes. Academy of management review, 16(1), pp.145-179.

Pan, Y., 2002. Equity ownership in international joint ventures: The impact of source country factors. Journal of International Business Studies, 33(2), pp.375-384.

Peng, M.W., 2002. Towards an institution-based view of business strategy. Asia Pacific Journal of Management, 19(2-3), pp.251-267.

Peng, M.W., 2003. Institutional transitions and strategic choices. Academy of management review, 28(2), pp.275-296. 
Peng, M.W., Wang, D.Y. and Jiang, Y., 2008. An institution-based view of international business strategy: A focus on emerging economies. Journal of international business studies, 39(5), pp.920936.

Perrons, R.K. and Platts, K., 2005. Make-buy decisions in the face of technological change: does industry clockspeed matter? International Journal of Management and Enterprise Development, 2(1), pp.1-11.

Petrescu, A.S., 2009. Science and technology for economic growth. New insights from when the data contradicts desktop models 1. Review of Policy Research, 26(6), pp.839-880.

Rajagopalan, N. and Datta, D.K., 1996. CEO characteristics: does industry matter? Academy of Management Journal, 39(1), pp.197-215.

Reuer, J.J. and Koza, M.P., 2000. Asymmetric information and joint venture performance: Theory and evidence for domestic and international joint ventures. Strategic management journal, 21(1), pp.81-88.

Santangelo, G.D. and Meyer, K.E., 2011. Extending the internationalization process model: Increases and decreases of MNE commitment in emerging economies. Journal of International Business Studies, 42(7), pp.894-909.

Schwens, C., Eiche, J. and Kabst, R., 2011. The moderating impact of informal institutional distance and formal institutional risk on SME entry mode choice. Journal of Management Studies, 48(2), pp.330-351.

Scott, W.R., 2005. Institutional theory: Contributing to a theoretical research program. Great minds in management: The process of theory development, 37(2005), pp.460-484.

Singal, M., 2014. Does Industry Matter for Diversity Management? In Academy of Management Proceedings (Vol. 2014, No. 1, p. 10591). Briarcliff Manor, NY 10510: Academy of Management.

Su, Y., 2015. R\&D and firm performance: How does local industry matter? In Academy of Management Proceedings (Vol. 2015, No. 1, p. 11506). Briarcliff Manor, NY 10510: Academy of Management.

Vasudeva, G., Nachum, L. and Say, G.D., 2018. A Signaling Theory of Institutional Activism: How Norway's Sovereign Wealth Fund Investments Affect Firms' Foreign Acquisitions. Academy of Management Journal, 61(4), pp.1583-1611.

Walter, J., Lechner, C. and Kellermanns, F.W., 2008. Disentangling alliance management processes: decision making, politicality, and alliance performance. Journal of Management Studies, 45(3), pp.530-560.

Waqar, W. T., 2020. Board size and acquisition outcome: The moderating role of home country formal institutional development. Managerial and Decision Economics, https://doi.org/10.1002/mde.3118

Weerawardena, J., O'Cass, A. and Julian, C., 2006. Does industry matter? Examining the role of industry structure and organizational learning in innovation and brand performance. Journal of business research, 59(1), pp.37-45.

Yang, C., Wang, Y. D., \& Niu, H. J. (2007). Does industry matter in attributing organizational learning to its performance? Evidence from the Taiwanese economy. Asia Pacific Business Review, 13(4), 547-563.

Yiu, D. and Makino, S., 2002. The choice between joint venture and wholly owned subsidiary: An institutional perspective. Organization science, 13(6), pp.667-683.

Zhang, Y., Zhong, W., Wen, N. and Jiang, D., 2014. Asset specificity and complementarity and MNE ownership strategies: The role of institutional distances. Industrial Marketing Management, 43(5), pp.777-785. 